Linguistik Terapan 14(3) (2017): 243-252

Jurnal Linguistik Terapan Pascasarjana

Available online http://jurnal.unimed.ac.id/2017/index.php/JLT-

Unimed

\title{
EXPERIENTIAL FUNCTION IN JOKO WIDODO'S SPEECH AT APEC CEO SUMMIT 2014 IN BEIJING, CHINA
}

\author{
Maragoti \\ Amrin Saragih \\ Sri Minda Murni
}

Diterima September 2017; Disetujui Oktober 2017; Dipublikasikan Desember 2017

\section{ABSTRACT}

This study presents a research conducted on Experiential Function in Joko Widodo's speech at APEC Summit 2014 in Beijing, China. The main objective was to describe the types and the dominant processes and Circumstances in Experiential Function in Joko Widodo's speech at APEC Summit 2014 in Beijing, China. It presented a qualitative design dealing with quantifiable (numeric) mode. The source of data was taken from Experiential Function in Joko Widodo's speech at APEC Summit 2014 in Beijing, China. The data were collected by applying documentary technique. The data analysis found out the findings indicating that there were 6 types of process used, they were 21 (22.11\%) Material Process, 39 (41.06 \%) Mental Process, 28 (29.47 $\%)$ Relational Process, 0 (0.\%) for Behavioral Process, 6 (6.36\%) Verbal Process, and $0(0 . \%)$ Existential Process. It means that the dominant pattern of Process is Mental. Meanwhile, there are 7 patterns of Circumstances found in the Joko Widodo's speech at APEC Summit 2014 in Beijing, China They are $0(0 \%)$ for Extent, 31 (32.63\%) for Location, 13 (13.68\%) for Manner, 5 (5.26\%) for Cause, $5(5.26 \%)$ for Contingency, $0(0 \%)$ for Accompaniment, and $0(0 \%)$ for Role. It means that the dominant pattern of Circumstance is Location. It proves that the use of Process and Circumstance were related to the context of situation.

Keywords: Experiantial Function, Jokowi's speech, Process.

How to Cite: Maragoti (2017). Experiential Function In Joko Widodo's Speech At Apec Ceo Summit 2014 In Beijing, China, 14 (3): 243-252

ISSN 2407-7410

\section{INTRODUCTION}

Language is the human capacity for acquiring and using complex systems of communication, and a language is any specific example of such a system. The scientific study of language is called linguistics. Language functions in our society as a principal means of communication. Being able to communicate effectively in English does not only mean to be proficient in the various 
language skills involved in the communication progress, but it also means to be able to use it effectively. When one is explaining something to another person, whether in speech or writing, s/he instinctively tries to organize what s/he says in a way that will make it easier for the hearer or the reader to understand. Therefore, it needs experiential function to express some meanings. Bell (2001:121) states that experiential function expresses cognitive meaning; the fundamental ideas conveying the function of language. This draws on the systems and networks of transtivity to create proportions, which convey the user's experience of the external world of the senses and inner world of the mind. It means that this function is related to Speech Fuction.

Speech function is used to fulfill human's needs in exchange of experience which is oriented to functional interpretation or systematic functional. It is also used to give a response in delivering some information from the speaker. In this case, experiential function is very important to be discussed because it has a constituent structure that can be described functionally in terms of process, participant, and circumstance with process being the essential ingredient. Sembiring (2009:35),in her thesis on the Experiential Function in the Texts of the Daily of the Jakarta Post, found that material is the dominant process and location is the dominant of circumstance. It means that material process is known as process of doing. It deals with the notion that some entity 'does' something which may be done 'to' some other entity. While, location circumstance tells about the time and place of event. It means that location is always used to describe the time and place of events of information clearly.

On $10^{\text {th }}$ November 2014, Joko Widodo, as the President of Indonesia delivered his speech on APEC CEO Summite in Beijing China. President Joko Widodo on Monday, November 10, 2014, became one of the key speakers at the prestigious APEC CEO Summit at the China National Convention Centre (CNCC), Beijing. Speaking before more than 1,500 CEOs from various countries, former Jakarta governor invited investors to come and bury their money in Indonesia.Unlike previous prediction, Jokowi delivered his speech in English.He delivered that there were several development projects in the wide-open chances reign era starting from the sea tolls, port development, power generation and power rails.

"We are waiting for you to come to Indonesia. We are waiting for you to invest in Indonesia," said Jokowi with fluent English.

In this study, the researcher intends to analyze whether the speech serves language development at best due to the Systemic Functional Linguistics especially by considering experiential function. In conclusion, the writer would like to see only by applying the process of the analysis of experiential function in JokoWidodo's speech at APEC CEO Summit 2014 in Beijing, China.

\section{REVIEW OF RELATED LITERATURE}

\section{Experiential Function}

Bell (2001:121) states that experiential function expresses cognitive meaning: the fundamental idea conveying function of language. This draws on the systems and networks of 
transitivity to create proportions which convey the user's experience of the external world of the senses and inner world of mind. Richard, John, \& Heidi (1992:389) state that transitivity is the choice between the processes that can be represented in a sentence. Related to the processes is participant and circumstance. A participant is someone or something involved in the process. Circumstance is the ways the process and participant are involved.

\section{Process}

Halliday (1994:107) states that processes are central to transitivity. There are three principle types of Process: Material, Mental, and Relational; and three subsidiary types of Process: Behavioral, Verbal, and Existential. Material Process is known as a process of doing. It deals with the notion that some entity 'does' something which may be done 'to' some other entity. It indicates events or activities. The common examples of verbs used in the process are kick, run, paint, dig, write, and etc. Mental Process refers to verbs indicating perception, cognition, and affection. It is known as a process of sensing. Downing \& Locke (2002: 125) states that mental process deals with perception (want, know, smell, taste, feel,think, imagine,). Relational Process construes being and relation among entities through attribution and identification. In other words, relational is known as process of being, and the term 'relational' is not 'being' in the sense of existing. Syntactically the process belongs to the copula construction. Behavioral Process refers to (typically human) physiological behavior (like breath, cough, smile, dream and stare). For examples: she dreams to buy a big apartment. The man stared at the woman seriously. Verbal Process show activities of saying, commanding, asking and offering. For examples:Now we talk about mass transportation. They always complain about land acquisition. Existential Process is known as a process of existing. It represents something exists of happens.

\section{Participant}

Halliday (1999: 112) states that participant is the person, creature, object, institution or abstraction that involves in a process. In experiential function, participant accompanies the six processes. Participant is inherent in the process. There are a number of a specific ways in which a participant may take part in a process; it may act out the process, it may sense through it, it may receive through it, it may be affected by it, it may say it. In the syntactic structure, the participants are typically realized by subject, direct object, and indirect object. Bell (2001: 127) describes that participant provides the answer to such questions as who/what, filling in detail of the immediate situation of utterance in which the process occurs and of which the text is a representation.

\section{Circumstance}

Circumstance is typically less closely associated with the process and is usually not inherent in it. Commonly, the circumstantial elements relate to extent, location, manner, cause, contingency, accompaniment, role, manner and angle. They occur freely in all types of processes. The interrogative 
forms for extent are for how long (temporal expression) and how far (spatial expressions) and where (spatial expressions). The circumstantial element of cause represents the reason for which a process takes place - what causes it. That is why the interrogative form is why. The interrogative form for contingency is in what circumstance, for accompaniment is together with, for role is what as, for matter is what about, and for angle is says who.

\section{RESEARCH METHOD}

This study used qualitative descriptive research design. The data of this research were the clauses found in Joko Widodo's speech at APEC CEO Summit 2014 in Beijing, China downloaded from the internet. The data source of this research was Joko Widodo's speech at APEC CEO Summit 2014 in Beijing, China. The data were collected by applying the documentary technique. The data of this research were analyzed based on Huberman and Saldana's theories (2014), the data were analyzed through three steps namely, data condensation, data display, and conclusion (drawing and verifying the result).

\section{FINDINGS AND DISCUSSIONS}

\section{Findings}

Realizations of Experiential Function are derived by analyzing the data. The data of this research were analyzed based on Halliday's theory (1994), the realizations are elaborated by analyzing the use of Processes and Circumstances. There are 6 types of Processes used in the Joko Widodo's speech at APEC CEO Summit 2014 in Beijing, China. They are Material, Mental, Relational, Existential, and Behavioral Processes. Meanwhile, there are 7 types of Circumstances used in the Joko Widodo's speech at APEC CEO Summit 2014 in Beijing, China. They are Extent, Location, Manner, Cause, Contingency, Accompaniment, and Role. Below, there are some examples of data analysis in the the Joko Widodo's speech at APEC CEO Summit 2014 in Beijing, China.

\section{A. Material Process}

1. We have started in Jakarta

Actor Prosess : Material Location

2. I will push my ministers, my governors, my mayors, to clear this problem.
Actor Process : Material
Goal

3. I go to the ground

Actor Process : Material Goal

B. Relational Process

1. I was a businessman a year ago

Token Process : Relational Location

2. I am very happythis morning 
Token Process : Relational Location

3. This isyour opportunity

Token Process : Relational Value

C. Mental Process

1. We need seaports and deep seaports

Senser Process : Mental Phenomenon

2. We need power plant

Senser Process : Mental Phenomenon

3. We have national one stop service

Senser Process : Mental Phenomenon

D. Verbal Process

1. Wecan talk about business, about investment with all of you Sayer Process : VerbalVerbiage

2. Now We talk about mass transportation LocationSayer

Process : VerbalVerbiage

3. Now We talk about our maritime agenda

Location Sayer Process : VerbalVerbiage

E. Behavioral Process

No Clauses

\section{F. Existential Process}

No Clauses

The proportion of Processes used in the speech is obtained by using the pattern introduced by Bungin (2005:171). It is:

Type of Process $=\mathrm{Fx} / \mathrm{N}$ x $100 \%$

$\mathrm{Fx}=$ Individual Frequency (one type of Process)

$\mathrm{N}=$ Total Number (all types of Process)

The results of the calculations are summarized in Table 4.2.2

Table 4.2.2 Types of Process

\begin{tabular}{|c|c|c|c|}
\hline No & Types of Process & Number & Percentages \\
\hline 1. & Material & 35 & 39.77 \\
\hline 2. & Mental & 14 & 15.90 \\
\hline 3. & Relational & 31 & 35.22 \\
\hline 4. & Behavioral & 0 & 0 \\
\hline 5. & Verbal & 8 & 9.09 \\
\hline \multirow[t]{2}{*}{6.} & Existential & 0 & 0 \\
\hline & Total & 88 & 100 \\
\hline
\end{tabular}

Table 4.2.2 shows that the total number of Material Process is 35 (39.77\%), Mental Process is 14 (15.90\%), Relational Process is 31 (35.22\%), Behavioral Process is $0(0 \%)$, Verbal Process is 8 (9.09\%), and Existential Process is $0(0 \%)$. It means that the dominant pattern of Process is Material. It is found that the speech is dominated by the use of material Process. 
To understand the Process in the speech, contextualization can be used to lead the readers to understand what the writers mean. There are three features of context, they are: Field, Tenor and Mode. The following examples can be understood through these features.

1. Most people struggled with falling incomes, rising costs, the slowest job growth in half a century

From the example 1, the context of the situation can be described through field, tenor, and mode as in the following.

Field : struggles with falling incomes, rising costs, the slowest job growth in half a century

Tenor : Most people

Mode : Direct

2. Small business owners cut back on expenses, but they keep theemployees

From the example 1, the context of the situation can be described through field, tenor, and mode as in the following.

Field : cut back on expenses, but they keep the employees

Tenor : Small business owners

Mode :Direct

Furthermore, there are 7 patterns of Circumstances found the Joko Widodo's speech at APEC CEO Summit 2014 in Beijing, China. They are Extent, Location, Manner, Cause, Contingency, Accompaniment, and Role.The proportion of Circumstance used in the speech is obtained by using the patternintroduced by Bungin (2005:171). It is:

Type of Circumstance $=\mathrm{Fx} / \mathrm{N} \times 100 \%$

$\mathrm{Fx}=$ Individual Frequency (one type of Circumstance)

$\mathrm{N}=$ Total Number (all types of Circumstance)

\section{A. Location}

1. I was a businessmana year ago

Token Process : Relational Location

2. I am very happythis morning

Token Process : Relational Location

3. The picture shows you our map ofIndonesia

Actor Process : Material Goal Location

B. Manner

1. Some subsidy we want to channel to fisherman to give them both engines and refrigerators Manner Actor Process : Material Goal

2. So this isyour opportunity Manner Token Process : Relational Value

3. So we need power plant

Manner Senser Process : MentalPhenomenon

C. Cause

1. Because you know 
Cause Process : Senser Mental

2. BecauseWe need power plant for manufacturing

Cause Senser Process : Mental Phenomenon

3. Because 143 families do not acceptthe compensation price

Cause Actor Process : Material Goal

D. Contigency

1. When they came to me Contingency Actor Process : Material

2. Then Wetalk about the problem four times meeting Contigency Sayer Process : Verbal Verbiage

3. Then Wetalk about the problem four times meeting Contigency Sayer Process : Verbal Verbiage

\section{E. Extent}

No Clauses

\section{F. Accompaniment}

No Clauses

G. Matter

No Clauses

H. Angel

No Clauses

\section{Role}

No Clauses

It can be seen on Table 4.2.3

Table 4.2.3 Types of Circumstances

\begin{tabular}{rccc}
\hline No & Types of Circumstances & Number & Percentages \\
\hline $\mathbf{1 .}$ & Extent & 0 & 0 \\
$\mathbf{2 .}$ & Location & 31 & 64.58 \\
$\mathbf{3 .}$ & Manner & 10 & 20.83 \\
$\mathbf{4 .}$ & Cause & 3 & 6.25 \\
$\mathbf{5 .}$ & Continency & 4 & 8.33 \\
$\mathbf{6 .}$ & Accompaniment & 0 & 0 \\
$\mathbf{7 .}$ & Role & 0 & 0 \\
$\mathbf{8 .}$ & Matter & 0 & 0 \\
9. & Angel & 0 & 0 \\
& Total & 48 & 100 \\
\hline
\end{tabular}

Table 4.2.3 shows that there are 7 patterns of Circumstances found inthe Joko Widodo's speech at APEC CEO Summit 2014 in Beijing, China. They are 0 (0 \%) for Extent, 31 (64.58\%) for Location, 10 (20.83\%) for Manner, 3 (6.25\%) for Cause, 4 (8.33\%) for Contingency, 0 (0 \%) for Accompaniment, $0(0 \%)$ for Role. It means that the dominant pattern of Circumstance is Location. It 
proves that Location Circumstance tells about temporal spatial where the time and place of event are made by the interesting information to be known by the readers. Therefore, the information in the Joko Widodo's speech at APEC CEO Summit 2014 in Beijing, China tries to describe the time and place of event to deliver the messages of the text to be easily grasped.

Through Circumstances, the readers can also understand the meaning of the sentences. It is through three features of context, they are Field, Tenor and Mode. The following examples can be understood through these features.

1. Deficits are still too high

From the example 1, the context of the situation can be described as:

Field : are still too high

Tenor : Deficits

Mode : Direct

2.States are still laying off teachers, first responders

From the example 2, the context of the situation can be described as:

Field :are still laying off teachers, first responders

Tenor : States

Mode : Direct

\section{Discussions}

Having analyzed the Joko Widodo's speech at APEC CEO Summit 2014 in Beijing, China based on Experiential Function, this study found that Material as the dominant Process and Location is the dominant of Circumstance. These findings can be in coordination with the study by Liping (2014) "The Material and Relational processes are most often chosen in political discourses because they present the statements of reality from the point of view of onlookers. So they seem to be more objective than other processes. And Mental processes also play a very important role in expressing the politician's ideas in this speech" (p. 130). Material process is known as a process of doing. It deals with the notion that some entity 'does' something which may be done 'to' some other entity. It indicates events or activities. The common examples of verbs used in the process are kick, run, paint, dig, write, and etc.

The findings of the verbal process used are supportive to the findings by Chen (2005) in regard to the use of neutral process in discourses. This suggests that Joko Widodo tends to make his statements believable and valid because the verbal clauses he employed function to introduce and shifting his declarations. Joko Widodo through Verbal processes comments on topics in order to provide people with information about the issues rather than reporting others' words or quotations. This also supports Liping's (2014) argument when he says "It is reasonable for a political speech to have a certain percentage of verbal processes since one of its characteristics is informative" (p.135). 
Besides, in the data Joko Widodo used verbal process to indicate what the West has fulfilled verbally to support the regions in Indonesia developments.

Semantically, material processes indicate activities or events, which happen in the outside world. One of the most salient types of processes are those involving physical actions (build, channel, scratch, cook, and sit down). For examples:We build our mass transportation in 6 big cities in Indonesia. Meanwhile, Location is the most dominant Circumstance. Location tells about the time and place of event. Location can guide the readers to understand the information through telling the time and place of event. It means that by knowing the Location, the readers can understand the information from the Joko Widodo's speech at APEC CEO Summit 2014 in Beijing, China. That is why Location Circumstance is the most dominant of others.

It can be concluded that Speech Function has role in delivering meaning of the texts. Speech Function is initiated by the speaker. A Speech Function by an addresser is responded by addressee. In this case, the reasons for the dominant Speech Functions are as in the following:

1. The information given is up-to-date to be discussed

2. The writers want to show their one way communication to describe the character of the politicians.

3. To attract the readers' attention to read the Joko Widodo's speech at APEC CEO Summit 2014 in Beijing, China.

\section{CONCLUSIONS}

This study explores the experiential and interpersonal meanings of SFL through the process systems in terms of the main issues Joko Widodo conveyed in his speech about Indonesia. The analysis of the data is limited to revealing the process and participant roles as parts of Experiental functions. It attempts to understand the construction and representation of Indonesia issues in his speech. This study is based on the work of Halliday; the pioneer of SFL and Matthessein (2014), and the works of followers Eggins, Thompson, and Fontain. This thesis on Experiential Function has been analyzed and based on the analysis, the researcher presents some valuable conclusions.

1. There are 6 types of Processes used in the Joko Widodo's speech at APEC CEO Summit 2014 in Beijing, China. They are Material, Mental, Relational, Existential, and Behavioral Processes. The dominant process used is Material.

2. There are 7 types of Circumstances used in the Joko Widodo's speech at APEC CEO Summit 2014 in Beijing, China. They are Extent, Location, Manner, Cause, Contingency, Accompaniment, and Role. It appears that the dominant type used is Location. 
3. Material process is known as a process of doing. In this speech, Joko Widodo would like to give good perception to the participants of APEC CEO Summit 2014 in Beijing, China that Indonesia is a potential place to invest and develop their business.

\section{REFERENCES}

Ary, D. 1979.Introduction to Research in Education. New York : Holt, Rinehart and Winston.

Bell, M. 2001. Functional Grammar. New York: Longman.

Bonifacio T. Cunanan 2017. Using Transitivity as a Framework in a Stylistic Analysis of Virginia Woolf's Old Mrs. Grey.Journal of Shanxi Normal University. Vol. 39, No.6, 150-155.

Chen Liping 2016. Experiential Metafunctional analysis of Winston S. Churchill's Speech on Hitler's Invasion of the U.S.S.R.Journal of Language and Linguistic Studies, 1(1) 53-66.

Downing, K \& Locke, J. 2002.Text.London : Longman.

Emery, M, Edwin, E, \& Nancy L. R. 2000.The Press and America. Boston: Allyn and Bacon.

Halliday, M.A.K. 1975. Learning How to Mean :Exploration in the Development of language. London: Edward Arnold.

Halliday, M.A.K, \&Hasan, R. 1999. Language, Context and Text : Aspect of Language in a Social Semiotic Perspective. Geelong: Deakin University.

Halliday, M.A. K \&Matthiessen, C. 1999. Working with Functional Grammar. Philadelphia: Moughton.

Hazelton, R. 1985. Language in Culture Society: A reader in Linguistics and Anthropology. New York : Harper and Row.

Junying Kang. 2017. A Functional Approach to the Status of Theme and Textual Development. Journal of the English Studies Association, 13/2, 50-67.

Luciana c. De oliveira. 2017. A Systemic-Functional Analysis of English Language Learners' Writing.Journalof TESOL France, 3/1: 87-104.

Mahya Alaei. 2016. A Study of Ideational Metafunction in Joseph Conrad's "Heart of Darkness": A Critical Discourse Analysis. Journal of English for Academic Purposes. 2, 103-123.

Richard, J \& Heidi, R. 1992. Discourse. San Fransisco. Longman.

Sembiring, S.S. 2009. The Experiential Function in the Texts of Daily of the Jakarta Post. Medan: Pascasarjana Universitas Negeri Medan. (Thesis). 